DOI: $\underline{\text { https://doi.org/10.34069/AI/2021.43.07.18 }}$

Al-Qemaqchi, N.T., \& Rauof, T.A. (2021). Assessing the habitability of single-family houses in Iraq a case study in Sulaimaniya city. Amazonia Investiga, 10(43), 175-188. https://doi.org/10.34069/AI/2021.43.07.18

\title{
Assessing the habitability of single-family houses in Iraq a case study in Sulaimaniya city
}

\author{
در اسية كحالة السليمانية مدينة العر اق في الاسرة منفردة المنازل في السكن قابلية تقييم
}

Received: May 21, 2021

Accepted: July 30, 2021

Written by:

Nahedh Taha Al-Qemaqchi ${ }^{67}$ https://orcid.org/0000-0003-2708-7807

Tara Azad Rauof ${ }^{68}$

https://orcid.org/0000-0002-8707-316X

\begin{abstract}
A residence strongly influences the lifestyle of its occupants and may be a determining factor for the family's quality of life. To maintain the comfort and well-being of its occupants, each dwelling should be adequate for the household. The dwelling should therefore provide a habitable and comfortable environment. Housing space standards in many countries set the conditions for achieving these objectives and generally regulate the overall sizes of individual rooms in addition to the layouts of dwellings.

This paper seeks to explore the relationship between habitable area ratios and other component area ratios, such as the structure area, the service area, the circulation area and the open space area, in the context of Iraqi single-family houses. Therefore, this study aims to answer two key questions: Is the habitable area ratio among other ratios compatible with Iraqi housing standards? And does it affect the performance of the units? To this end, the paper adopted a methodology for calculating each area ratio in several newly established complexes in Sulaimaniya City and their relationship to the size of different plot areas for assessing the habitability and efficiency of different house plot areas.
\end{abstract}

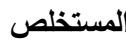

Keywords: Habitability, Habitable area ratio, Iraqi housing, Residential Standardization, Single-family house.

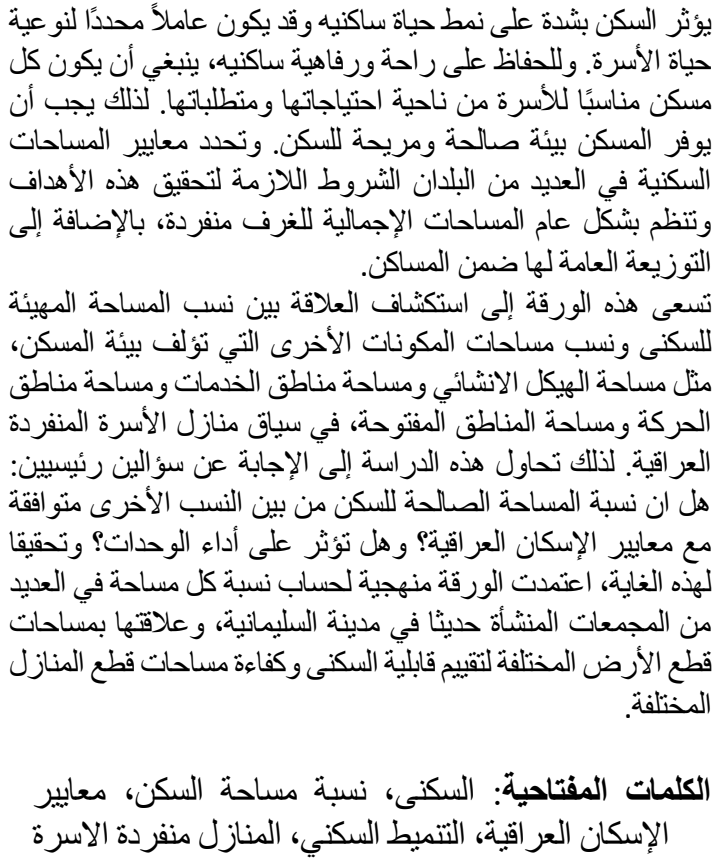

\footnotetext{
${ }^{67} \mathrm{PhD}$. in Theory of Design \& Design Methodology. Assistant Professor, Department of Architectural Engineering, Cihan UniversitySulaimaniya, Kurdistan Region, Iraq.

${ }^{68}$ M.Sc. in Hybrid Building. Lecturer, Department of Architectural Engineering, Cihan University-Sulaimaniya, Kurdistan Region,
} Iraq. 


\section{Introduction}

Most Iraqi cities are suffering from a major housing crisis, resulting from overcrowding of dwellings, (informal) subdivisions of existing housing units or plots where it is noted that the number of families occupying one dwelling (formally subdivided) continues to increase (UHSM, 2010). In addition, the outdated housing stock and the resulting deterioration in terms of both construction and services have been clearly observed (The Iraqi Central Statistical Origination (ICSO), 2009). The estimated housing deficit in Iraq was approximately 2 million units at the end of 2016 (UN-Habitat, \& World Bank/IFC. 2006), this figure was calculated based on statistical projections of the General Census conducted in Iraq in 1997 (The Iraqi Ministry of Planning, 2018).

The crisis of housing leakage became prominent in recent decades after many wars and was mainly solved through introducing a new series of residential projects that offered respectable quality accommodations for middle- and lowincome households (World Bank Group, 2018). These projects have provided mixed layouts to fulfil the needs of the residents. Different plot areas were adopted, but most of them went towards developing relatively small areas for economic and investment considerations (ECOM, UN-Habitat, 2010). Most of these projects have been based on varying standards to achieve design solutions for houses with different spatial configurations. This was done to achieve the highest benefit for the client, without any regard to the habitability provided by the buildings for their occupants. Therefore, the designs came at the expense of the functional habitability of the housing and what could have been achieved for residents (Al-Qemaqchi, 2019).

This inconsistency between the strategy of these companies for increasing their profits and the requirements of the family has forced families to conform to the available space stipulated for these housing units at the expense of habitability and efficiency. Consumer satisfaction, housing policy, and housing market mechanisms are, driven by the government and large private construction companies. The result of this system could be described in that despite paying money in advance, people did not receive the kind of housing that they wanted. In other words, the housing sales mechanism allows construction firms to earn a profit at low cost, and the government to earn money through land sales and the bond market.

\section{Research Problem and Scope}

Housing activities have a more or less pronounced strategic dimension. This strategy can vary in complexity from a pure survival strategy, as in many Third World countries, to strategies for wealth representation and social stability. Both strategies seek to allocate resources to achieve household goals.

Home-ownership in Iraq (for middle-and lowincome families) typically follows one of two strategies. The first strategy is self-construction, in which, families play a significant part in interacting with architects, contractors and construction workers, but this is not an action that can be carried out on an individual basis. (UNHabitat \& World Bank/IFC., 2006). Moreover, this action depends on the family budget or receiving financial assistance from public and/or private institutional entities and then finding appropriate plots in an ordinary neighbourhood in the city, which can entail disadvantages regarding power sources, water supply, privacy and, most importantly security issues. That is why this strategy is much less employed in large cities such as Sulaimaniya.

The second strategy is purchasing a preconstructed housing unit. Families usually attempt to buy a unit (an apartment or a singlefamily house) that accommodates their needs in a compound in the city, which offers higher construction and life quality in addition to other social advantages. These pre-constructed housing units are built by private investment companies or by government institutions through contracting with private construction firms that follow more or less the standards proposed by these firms themselves with only general guidelines from authorities. Families who buy pre-constructed houses in residential complexes are often forced to accept those units with their specified areas and spatial organization with little possibility of modification and are therefore forced to adapt their needs to the design of these units. Despite all these disadvantages, this strategy is becoming increasingly popular.

This research aims to study the habitability of single-family houses offered in newly established housing complexes built by investment companies. Four research questions are addressed:

1) Is the ratio of habitable floor area to the total built-up area of the house acceptable? 


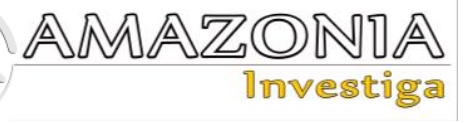

2) Is the ratio of the other floor areas (service floor area, open space floor area, etc.) to the total built-up area of the house acceptable?

3) Is there any correlation between these areas and the plot area of the single-family house?

4) Finally, how well do these floor ratios match the Iraqi regulations?

\section{Literature review}

\section{House Space Standards}

It is commonly understood that a dwelling should be large enough to satisfy the requirements of its occupants for the activities of living, cooking, dining, sleeping, bathing, and storage; these should be sufficient spaces to insure their functionality. Space standards in many countries establish the requirements to obtain these objectives and usually regulate the overall area, dimensions of individual rooms, and layout of the dwelling.

It is important to note that housing standards have been the subject of concern by many international organizations, including the World Health Organization (WHO), which has focused its attention (especially in developing countries) on housing deficiencies and has created endemic areas as a result of the lack of necessary health and safety standards (Howden-Chapman, et. al., 2017).

As Rapoport (1991) previously pointed out in his book (House Form and Culture), a dwelling reflects the image of family life and hence the society that composes it with its culture, traditions, and environmental aspects (Rapoport, 1991). Building regulations are one of the most vital tools that guarantee an adequate quality of the built environment. Space standards are a measure of occupant satisfaction of dwellings in the context of certain cultural, social, climatic, economic, and technological conditions (Chowdhury, 1985). These conditions change with time, meaning that space standards should be updated regularly (Matthew, 2009). Additionally, these standards must be appropriate to absorb the changes in a family's life according to their life cycle and to achieve sufficient flexibility to accommodate changes in their needs (Femenias \& Geromel, 2019).

The creation of good and adequate space standards is important for several reasons (Towers, 2000, Pedro, 2009, Park, 2017):

1) There is evidence that overcrowded conditions can lead to interpersonal violence, family isolation, psychological disorder, or physical illness. In addition, small homes that do not support the needs of occupants may lead to problems of social stability, and negative social behaviours.

2) As homes, have a long lasting life, it is not easy to determine the evolution of consumer requirements and their consequences for space quality. The flexibility of a dwelling enables it to be adjusted to the changing needs of people but relies strongly on its initial spatial characteristics. Smaller residences have less space and do not meet the needs of growing families and thus, a broader variety of options is necessary.

3) The space characteristics of a house, which have been defined during design and construction, are difficult to alter. Spatial improvements typically require expensive reconstructions.

4) Houses with suitable spaces are likely to be perceived as more attractive to homebuyers and therefore produce a higher real estate or rental value.

Standardization and quality control of housing are considered important issues to solidify sustainability societies and institutions have been slow to respond to the environmental imperative regarding the design and construction of housing, although housing is an important element of the environment (Franklin, 2006).

Regarding the modification of existing spaces in the housing unit, Thabit et al, (2007) has stated in her article that the use of spaces according to the housing unit design is presumed to be consistent with the reasons for the actual use of these spaces, and this consistency is complete if the design meets the requirements of the occupants. This use of spaces relates to economic, social and demographic factors, as well as the role that the characteristics of the housing unit themselves play in the style of space. The effect of eliminating a single space causes occupants to modify parts of other spaces to satisfy the lost needs and thus affects the efficient performance of the existing spaces' functions.

The ability to respond to inhabitant requirements increases the sustainability of the housing unit, as a flexible house means a house that can adapt to the changing needs of its users, leading to reduction in household transitions from one unit to another. On the other hand, the sustainable perspective imposes a decrease in extravagant residential use of available urban land, which ultimately leads to the spread of the city over a large area and wastes its requirements in the 
services required for the established residential neighbourhoods established (Yakob, et al., 2013).

As housing development increases and supports the economy of the country, it also creates negative impacts in terms of environmental and social aspects. Several scholars have pointed to the role standards play in forming housing policies in the world (Pedro, 2009; Gallent, et al., 2010). In addition, countries should review and adjust their housing standards from time to time based on economic, social and environmental considerations to ensure the comfort and safety of occupants (Hooper \& Nicol, 1999; Allen, et. al., 2008, Thabit, et al., 2007; Tabak, et al., 2010).

\section{Housing policies in Iraq}

For most Iraqi citizens, housing is the largest single investment of their lifetime. This is especially true considering that families seek simple investments, stability, and a path to a guaranteed future. Developing countries have learned that providing affordable homes for all cannot be left to market forces alone. Although few elites face no trouble purchasing comfortable homes, most families in developing countries have insufficient accommodation and related services. (Salih, 2015).

In Iraq, the physical evaluation of the various housing programmes is difficult. Due to the lack of data on ordinary neighbourhood stocks, housing units are developed with residential programmes, other than the Iraq National Investment Authority (INA) housing programme. Although most of these programmes were well designed in terms of their objectives, they could not contribute to solving much because of their reliance on the central government for funds and the difficulty of suitable programme formulation at a national level based on city feedback. If the goals are political and administrative instead of economic considerations reflecting the real situation, the programmes also lack the participation of the public in planning and implementation (Al-Shaibani, \& Popov, 2019).

Political instability and the security situation have played a significant role in the failure of implementation of Iraq housing programmes, especially after 2003. Despite the provision of banking programmes (such as borrowing from the Iraq Housing Bank), the mechanisms and administrative aspects led to failure to achieve its objectives and did not have an effective impact on the increase in housing stock in the country. All of the abovementioned obstacles led to the appearance of residential neighbourhoods that were not planned and had no services or infrastructure, reflecting the lack of urban planning and the scarcity of urban land used for effective urban programmes. Eventually the prices of properties increased remarkably, which led to the inability of individuals to own a property or even live within an environment of high commodity prices and reduced availability of employment opportunities (Al-Shaibani \& Popov, 2019).

One of the best developed programmes is that of the Investment Authority to build one million housing units across the Iraqi provinces. However, this programme may not be successful due to the scarcity of urban land, the lack of clarity of the land ownership and the inflexibility of politicians in implementing the programmes. The Investment Authority did not adopt its own standards and patterns of housing to increase the number of housing units in its programmes, such as the size, area of the housing unit, available services, or public roads (Abrahem, 2018).

This was a reason for the emergence of many nongovernmental companies and foreigner firms to implement their programmes in a pattern of long-term real estate investment in the residential sector, which helped to provide many housing units for investment (Salih, 2015).

\section{Iraqi housing standards}

The Iraqi Urban Housing Standards Manual (UHSM), which was first published in October 2010 by the Ministry of Housing and Construction State/Commission of Housing Studies Section, stipulates the execution of a general housing policy to ensure adequate housing for Iraqi citizens. The manual addresses the most important planning and design criteria used by the State Commission of Housing in the preparation of detailed programmes of planning and designing housing complexes (UHSM. 2010).

This manual contains the most critical criteria needed for the preparation of proposals, studies, and styles of residential complexes mostly organized in tables and elaborative illustrative drawings (Ministry of Housing and Construction, 1983). The technical standards in this manual represent a general guideline for planning and design. On the other hand, these criteria should not be generalized but should be specifically evaluated on a case by case basis using the best 


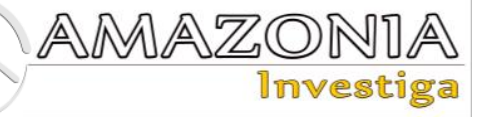

possible criteria to realize a final standard for guidelines. The manual defined the habitable dwelling area as the total area specified for living and sleeping (given in square metres) and considered it to be the main area for family habitation compared to other facility areas.

According to the standards, the ratio of habitable floor area to other floor area ratios must be as high as possible to achieve efficient utilization of the floor area. Thus, to analyse this ratio, this paper aims to disclose the relationship between the habitable floor area and other components, such as the structure floor area, service floor area, circulation floor area, and open space floor area, to determine the housing efficiency of these projects.

Housing quality control procedures in Iraq include varied standards compiled from various sources. There is no specific obligatory system in Iraq for developing and using standards by either government agencies or the private sector. In addition, there is no means to assess whether any standards have been applied. The Ministry of Housing and Construction is also developing and adopting a new building code that will outline construction standards for housing. Municipal governments are responsible for overseeing the issuance of building permits, although governors or central officials will usually be involved in approving major development projects (UNHabitat, World Bank/IFC. 2006).

Previous studies have cited the problems of the spatial organization of residential buildings in Iraq and attribute these issues to several reasons. One reason is that the regulations cannot suit the requirements of the Iraqi family, as Al-Hafith et al, (2018) pointed out in his article (A Systematic Assessment of Architectural Approaches for Solving the Housing Problem in Iraq), as families attempt to move to new houses according to changes in their life cycle (Al-Hafith, et al., 2018), Al Khafajy (2018) mentioned the problem of internal spaces in the housing unit in particular, the inability to evolve with the changes in Iraqi family composition and the inability to achieve a minimum degree of sufficient flexibility to accommodate these changes (Al Khafajy, et al., 2018). Mahmood (2011) stated that building companies offer a collection of standard types with a range of different internal layouts for each market segment (Mahmood, 2011). For each house type, a limited range of internal design options can be offered to accommodate consumer preferences or the preferences of the local planning authority. The problem of fitting standard house types to specific scheme layouts is addressed in different ways by different companies (AL-Temimi, \& AlSaidi, 2014). Previous published studies have researched the housing problem in Iraq in terms of layout, spatial organization, suitability and flexibility. The current paper attempted to assess the habitability of housing complexes using the Urban Housing Standards Manual as a guideline.

Polservice was the first international expert company that was commissioned by the Ministry of General Municipalities in 1983 to perform a comprehensive study of housing in Iraq which resulted in a comprehensive system of housing standards (Ministry of Housing and Construction, 1983) that were supposed to become the strategic structure of the housing policy for Iraq during that period (Ministry of Housing and Construction, 1983). The lack of seriousness from responsible authorities and the circumstances of the country at that time prevented that system from being approved. This issue did not prevent the system from being taken as an unofficial document for the housing policy in Iraq, although the contained standards as general criteria were still not obligatory (Ministry of Housing and Construction, 1983).

\section{Iraqi housing spaces}

From the declared classification it is possible to conclude that each house is composed of five main area subdivisions: first, the habitable area, including the total area for sleeping, living, daily activity, and dining; second, the structure area, including the area occupied by the structure system of the house; third, the service area, which includes the total areas for food preparation, bath, WC and storage area; fourth, the circulation area, which includes the staircase, corridors, entrance lobby, and internal halls; and finally, the open area, which includes gardens, open courts, shafts, and balconies. The standard minimum recommended area assigned by the Iraqi Urban Housing Standards Manual (UHSM) was documented in several tables to constitute a general guideline indicator for developers (UHSM, 2010), as these standards indicate the minimum recommended areas [Table 1]. 
Table 1.

Single-family houses plot area range and corresponding floor areas according to UHSM standards (Researchers).

\begin{tabular}{|c|c|c|c|c|c|c|}
\hline $\begin{array}{l}\text { Plot area } \\
\text { range } \mathrm{m}^{2}\end{array}$ & $\begin{array}{l}\text { Average } \\
\text { built-up } \\
\text { area } \mathrm{m}^{2}\end{array}$ & $\begin{array}{c}\text { Average } \\
\text { open } \\
\text { area m2 }\end{array}$ & $\begin{array}{l}\text { Average } \\
\text { structure } \\
\text { area } \mathrm{m}^{2}\end{array}$ & $\begin{array}{c}\text { Average } \\
\text { circulation } \\
\text { area m² }\end{array}$ & $\begin{array}{l}\text { Average } \\
\text { service } \\
\text { area } \mathrm{m}^{2}\end{array}$ & $\begin{array}{c}\text { Average } \\
\text { habitable } \\
\text { area } \mathrm{m}^{2}\end{array}$ \\
\hline $150-210$ & 81 & 9 & Not assigned & 9 & 18 & 48 \\
\hline $220-290$ & 105 & 15 & Not assigned & 12 & 23 & 63 \\
\hline $240-320$ & 120 & 21 & Not assigned & 15 & 23 & 75 \\
\hline $340-380$ & 157 & 27 & Not assigned & 21 & 32 & 93 \\
\hline $360-400$ & 180 & 33 & Not assigned & 24 & 36 & 108 \\
\hline $460-600$ & 190 & 39 & Not assigned & 27 & 36 & 120 \\
\hline
\end{tabular}

\section{Case Studies}

Sulaimaniya is an Iraqi city located in northeastern of Iraq and belongs to the Kurdistan Region, occupying an area of 3404 sq.km, with a population of more than one million (The Iraqi Central Statistical Origination (ICSO), 2009). The local government began investing in the housing sector and dozens of new housing complexes have appeared in the city since 2000 . To investigate the habitability of these new housing complexes, three residential projects have been chosen in the city of Sulaimaniya to guarantee diversity of residential types.

The first project is Lubnan City, located in the southwest of the city, established in 2010 and completed in 2012, on a total area of 109347 sq. m. It contains 296 single-family house units with 3 different plot areas (150 sq. m plot area, 200 sq. $\mathrm{m}$ plot area and 300 sq. m plot area). (Kurdistan Regional Government-Iraq, 2019)

The second project is Qaiwan City, located west of the city, established in 2007 and completed in 2013 with a total area of 295500 sq. m, which is one of the largest residential complexes in Iraq. It contains 340 single-family house units with 6 different plot areas (600 sq. m plot area, $400 \mathrm{sq}$. $\mathrm{m}$ plot area. 480 sq. $\mathrm{m}$ plot area. 330 sq. $\mathrm{m}$ plot area, and 440 sq. m plot area). (Kurdistan Regional Government-Iraq, 2019)

The third project is New Chwar-Chra City, located south of the city, established in 2010 with three phases; the first phase was completed in 2017, with a total area of 517256 sq. m. It contains 802 single-family house units with 4 different plot areas (200 sq. m plot area, 240 sq. $\mathrm{m}$ plot area, 300 sq. $\mathrm{m}$ plot area, and 700 sq. $\mathrm{m}$ plot area). (Kurdistan Regional GovernmentIraq, 2019)

\section{Study Samples and Research Methodology}

Since the beginning of the century, the local government in the Kurdistan Region of Iraq has made real estate investments in the residential sector possible. As a result, many companies have invested in this sector and created many housing projects with multiple unit types for single-family housing. We chose three housing projects recently set up in the city of Sulaimaniya that include includes individual residential units, varying in their design, layout, and construction methods. Then, from these projects, only 30 samples of single-family houses were selected due to the large number of houses offered.

The selections of the residential samples from the three case studies were made according to the following criteria:

1) All the sample units consist of two floors.

2) All the sample units are suitable for singlefamily housing.

3) No modification is made to any units' original layout.

4) There is variety in the units' area.

5) There is variety in spatial organization and layout.

6) There is variety in the units' structure (skeleton system and load-bearing wall 
system) and construction materials (brick, concrete blocks, thermos stone block, etc.).

From the three previously chosen case studies, a selection of 30 samples in total was taken and categorized into eight groups in terms of their square metre plot area ranging from plot areas of $150-200$ sq. $\mathrm{m}$ to over $500 \mathrm{sq}$. $\mathrm{m}$. The plot areas were set as ranges due to the differentiation of the plots available in the study cases. Each group

Table 2.

Samples plot area range with their corresponding areas (Researchers).

\begin{tabular}{llllllll}
\hline $\begin{array}{l}\text { Plot area } \\
\text { range } \mathbf{~ m}^{2}\end{array}$ & $\begin{array}{l}\text { No of } \\
\text { sampl } \\
\text { es }\end{array}$ & $\begin{array}{l}\text { Average } \\
\text { built-up } \\
\text { floor } \\
\text { area } \mathbf{m}^{2}\end{array}$ & $\begin{array}{l}\text { Average } \\
\text { open } \\
\text { floor } \\
\text { area } \mathbf{m}^{2}\end{array}$ & $\begin{array}{l}\text { Average } \\
\text { structure } \\
\text { floor area } \\
\mathbf{m}^{2}\end{array}$ & $\begin{array}{l}\text { Average } \\
\text { circulation } \\
\text { floor area } \\
\mathbf{m}^{2}\end{array}$ & $\begin{array}{l}\text { Average } \\
\text { service } \\
\text { floor } \\
\text { area } \mathbf{m}^{2}\end{array}$ & $\begin{array}{l}\text { Average } \\
\text { habitable } \\
\text { floor area }\end{array}$ \\
\hline $\mathbf{1 5 0 - 2 0 0}$ & 2 & 171.7 & 63.2 & 27.6 & 45.9 & 34.5 & 113.7 \\
\hline $\mathbf{2 1 0 - 2 5 0}$ & 5 & 189.8 & 94.6 & 32.1 & 47.8 & 42.9 & 110.4 \\
\hline $\mathbf{2 6 0 - 3 0 0}$ & 4 & 210.9 & 102.2 & 34.8 & 55.4 & 58.4 & 118.2 \\
\hline $\mathbf{3 1 0 - 3 5 0}$ & 5 & 243.3 & 113.3 & 37.7 & 58.2 & 75.3 & 125.5 \\
\hline $\mathbf{3 6 0 - 4 0 0}$ & 3 & 285.4 & 133.4 & 41.5 & 61.5 & 80.1 & 137.4 \\
\hline $\mathbf{4 1 0 - 4 5 0}$ & 3 & 299.4 & 180.8 & 42.2 & 64.5 & 84.5 & 147.4 \\
\hline $\mathbf{4 6 0 - 5 0 0}$ & 3 & 310.4 & 210.4 & 44.5 & 70.4 & 90.1 & 155.2 \\
\hline $\mathbf{O v e r} \mathbf{5 0 0}$ & 5 & 421.4 & 381.2 & 46.1 & 74.6 & 95.6 & 210.1 \\
\hline
\end{tabular}

Each sample was analysed, and its areas were measured to calculate the total existing area, for example, of the habitable area and the other included a different number of samples due to the available similar samples in each case study. To analyse these samples and compare their areas to the manual, we had to first calculate the average built-up floor area of the samples belonging to each group in addition to calculating five other components, namely, the open floor area, structure floor area, circulation floor area, service floor area and finally the habitable floor area as listed in Table 2. 


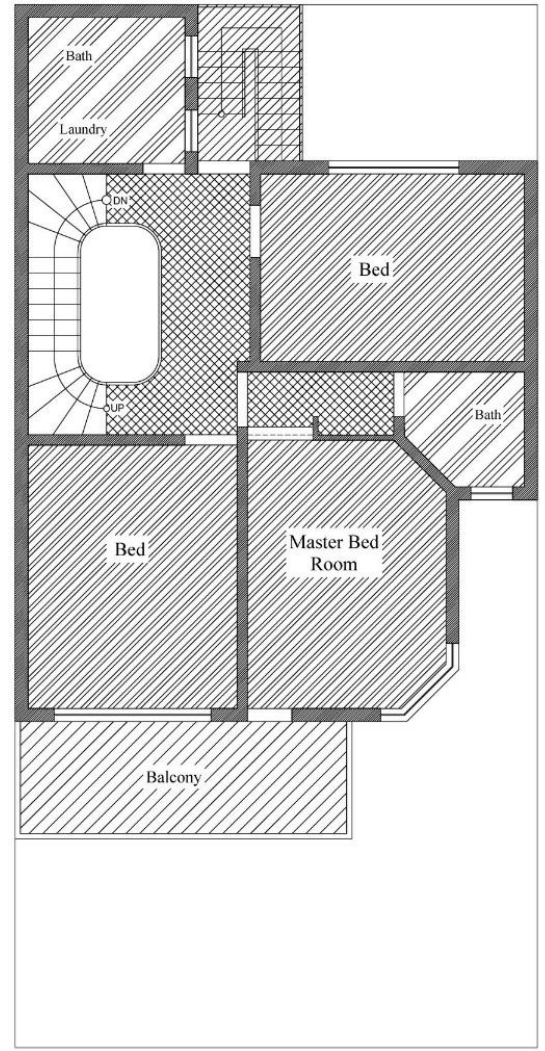

First Floor Plan

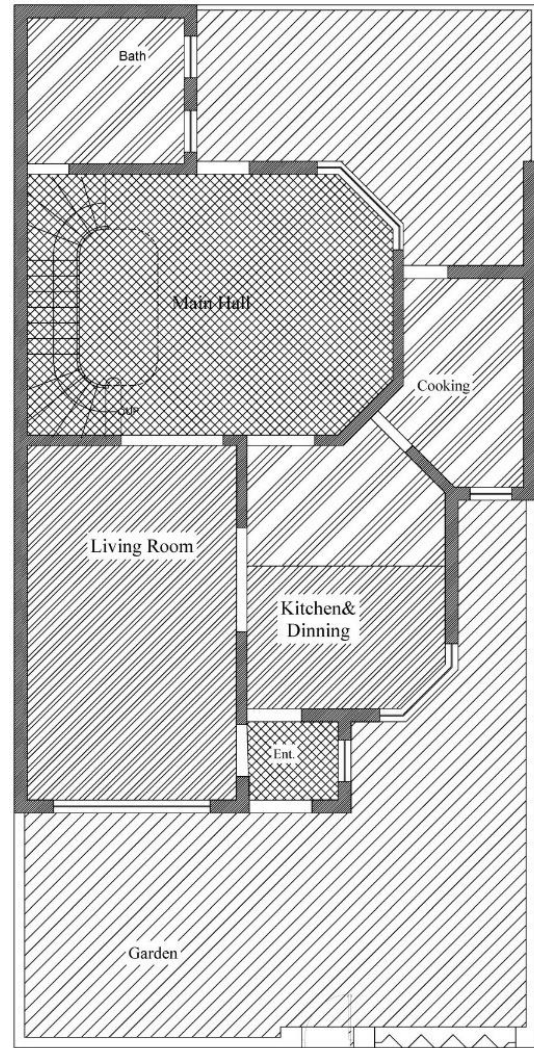

Ground Floor Plan

Figure 1. The layout of 160 sq. m. unit (Researchers).

According to the standards given by the UHSM, the calculation of the floor area ratio per component to the total built-up area is shown in Table 3 .

\section{Table 3.}

The ratios of all components to the total built-up area for each Single-family house according to (UHSM) standard's (Researchers).

\begin{tabular}{llllll}
$\begin{array}{l}\text { Plot area } \\
\text { range } \mathbf{~ m}^{2}\end{array}$ & $\begin{array}{l}\text { Open area } \\
\text { ratio\% }\end{array}$ & $\begin{array}{l}\text { Structure } \\
\text { floor area } \\
\text { ratio\% }\end{array}$ & $\begin{array}{l}\text { Circulation floor } \\
\text { area ratio\% }\end{array}$ & $\begin{array}{l}\text { Service floor } \\
\text { area ratio\% }\end{array}$ & $\begin{array}{l}\text { Habitable } \\
\text { floor area } \\
\text { ratio\% }\end{array}$ \\
\hline $\mathbf{1 5 0 - 2 1 0}$ & 11.1 & Not assigned & 11.1 & 22.2 & 59.3 \\
\hline $\mathbf{2 2 0 - 2 9 0}$ & 14.3 & Not assigned & 11.4 & 21.9 & 60.0 \\
\hline $\mathbf{2 4 0 - 3 2 0}$ & 17.5 & Not assigned & 12.5 & 19.2 & 62.5 \\
\hline $\mathbf{3 4 0 - 3 8 0}$ & 17.2 & Not assigned & 13.4 & 20.4 & 59.2 \\
\hline $\mathbf{3 6 0 - 4 0 0}$ & 18.3 & Not assigned & 13.3 & 20.0 & 60.0 \\
\hline $\mathbf{4 6 0 - 6 0 0}$ & 20.5 & Not assigned & 14.2 & 18.9 & 63.2 \\
\hline
\end{tabular}


While the case study samples floor area ratio of each component to the total built-up area was calculated and shown in Table 4.

Table 4.

The ratios of all components to the total built-up area for each sample according to the case study samples (Researchers).

\begin{tabular}{llllll}
\hline $\begin{array}{l}\text { Plot area } \\
\text { range } \mathbf{~ m}^{2}\end{array}$ & $\begin{array}{l}\text { Open floor } \\
\text { area ratio } \\
\%\end{array}$ & $\begin{array}{l}\text { Structure } \\
\text { floor area } \\
\text { ratio\% }\end{array}$ & $\begin{array}{l}\text { Circulation floor } \\
\text { area ratio\% }\end{array}$ & $\begin{array}{l}\text { Service } \\
\text { floor area } \\
\text { ratio\% }\end{array}$ & $\begin{array}{l}\text { Habitable floor } \\
\text { area ratio\% }\end{array}$ \\
\hline $\mathbf{1 5 0 - 2 0 0}$ & 36.8 & 16.1 & 26.7 & 20.1 & 66.2 \\
\hline $\mathbf{2 1 0 - 2 5 0}$ & 49.8 & 16.9 & 25.2 & 22.6 & 58.2 \\
\hline $\mathbf{2 6 0 - 3 0 0}$ & 48.5 & 16.5 & 26.3 & 27.7 & 56.0 \\
\hline $\mathbf{3 1 0 - 3 5 0}$ & 46.6 & 15.5 & 23.9 & 30.9 & 51.6 \\
\hline $\mathbf{3 6 0 - 4 0 0}$ & 46.7 & 14.5 & 21.5 & 28.1 & 48.1 \\
\hline $\mathbf{4 1 0 - 4 5 0}$ & 60.4 & 14.1 & 21.5 & 28.2 & 49.2 \\
\hline $\mathbf{4 6 0 - 5 0 0}$ & 67.8 & 14.3 & 22.7 & 22.7 & 49.9 \\
\hline $\mathbf{0 v e r} 500$ & 90.5 & 10.9 & 17.7 & 29.0 & 50.0 \\
\hline
\end{tabular}

\section{Results and Discussion}

The floor area ratio values calculated in Table 4 and Table 3 are sketched separately per component in graphs to visualize the differences or similarities between the UHSM and the case samples from the case studies.
Starting with figure 2, the average plot areas and the habitability ratios are used. Case studies have shown an obvious inverse correlation between the average plot area and the habitability indicators, while the UHSM indicator remains stable. The most striking observation is that with the increase in the average plot area, the incompatibility between the two lines increases. 


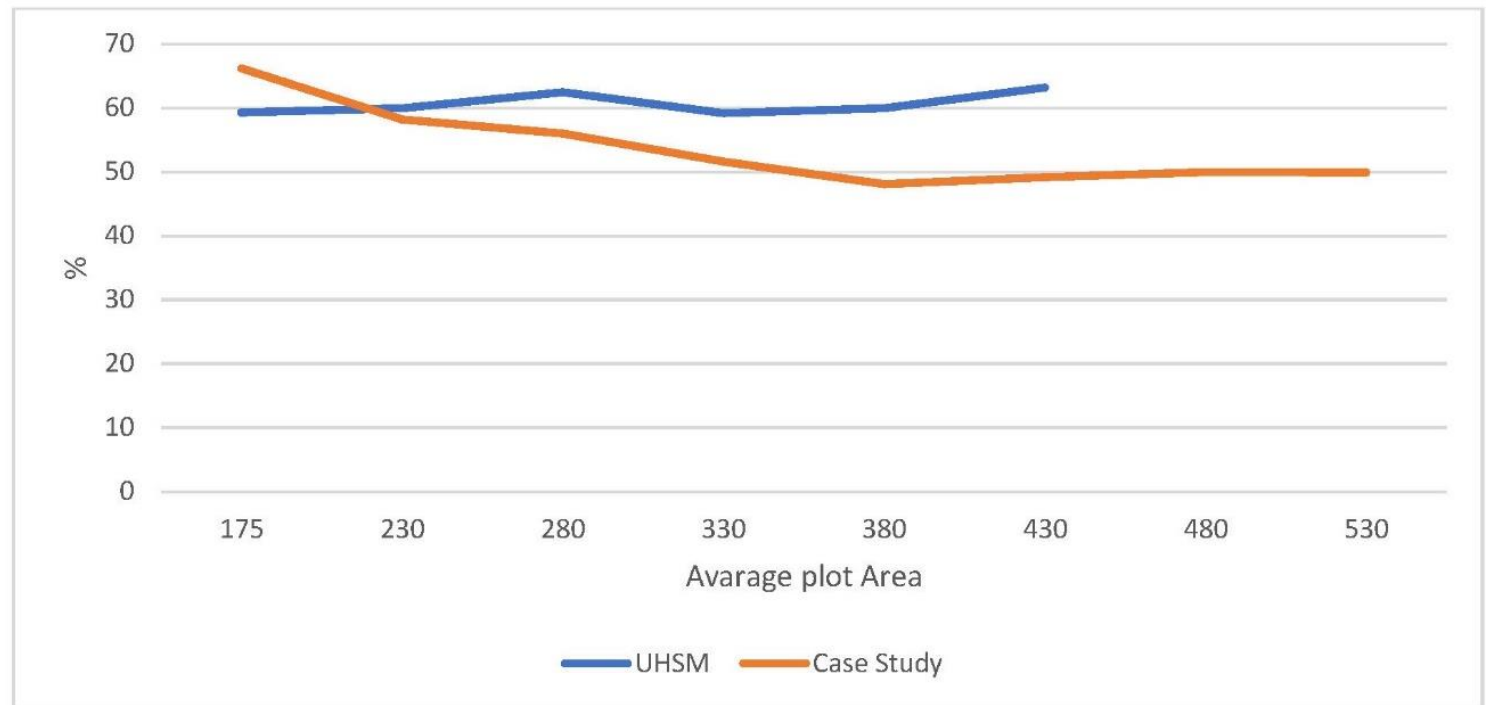

Figure 2. The relationship between the habitability ratios and the average plot areas of the (UHSM) and case study sample (Researchers).

Figure 3 shows the changes occurring in the service floor area ratios and the average plot area. There is a clear discrepancy detected from the graph [Figure 3], by determining a direct correlation between the amounts of the equivalent services area ratio and the average plot areas in the case studies while the (UHSM) standards remain stable. This is not consistent with the needs of the residents for services that support their vital needs.

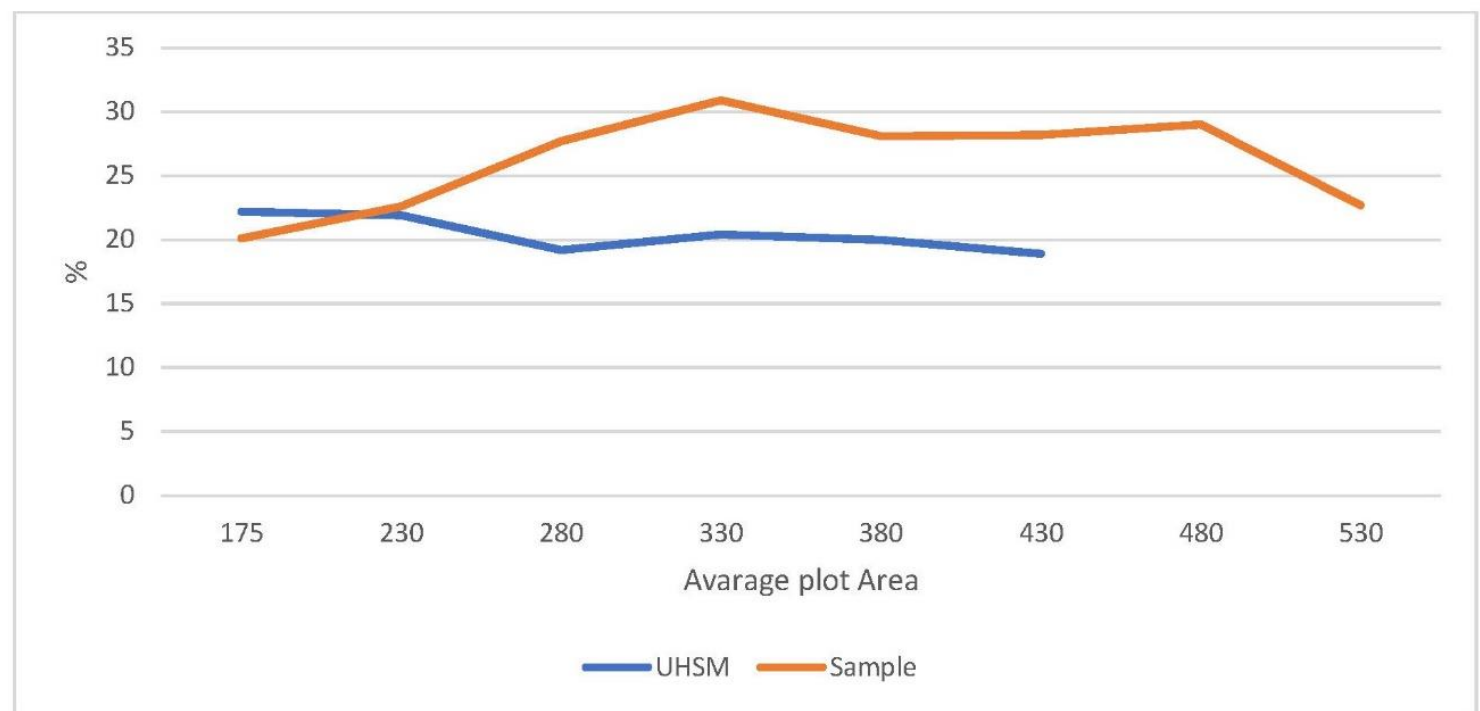

Figure 3. The relationship between the service floor area ratios and the average plot areas of the (UHSM) and case study sample (Researchers).

At the same time, as the average plot area increases, the floor area ratio of the circulation system sharply drops from $26.7 \%$ to $17.7 \%$ within the case study samples, while the service ratios gradually increase with increasing plot areas in the UHSM standards [Figure 4]. It can be observed that these values are inconsistent. Inhabitants' need for comfortable horizontal and vertical communication systems is higher with a larger plot area within an acceptable level. In our opinion, it also indicates that the spatial arrangement of the house layout is based on the expansion of living and sleeping rooms within the dwelling at the expense of other supporting facilities that eliminate the ability of the residents to manipulate the use of the house. 


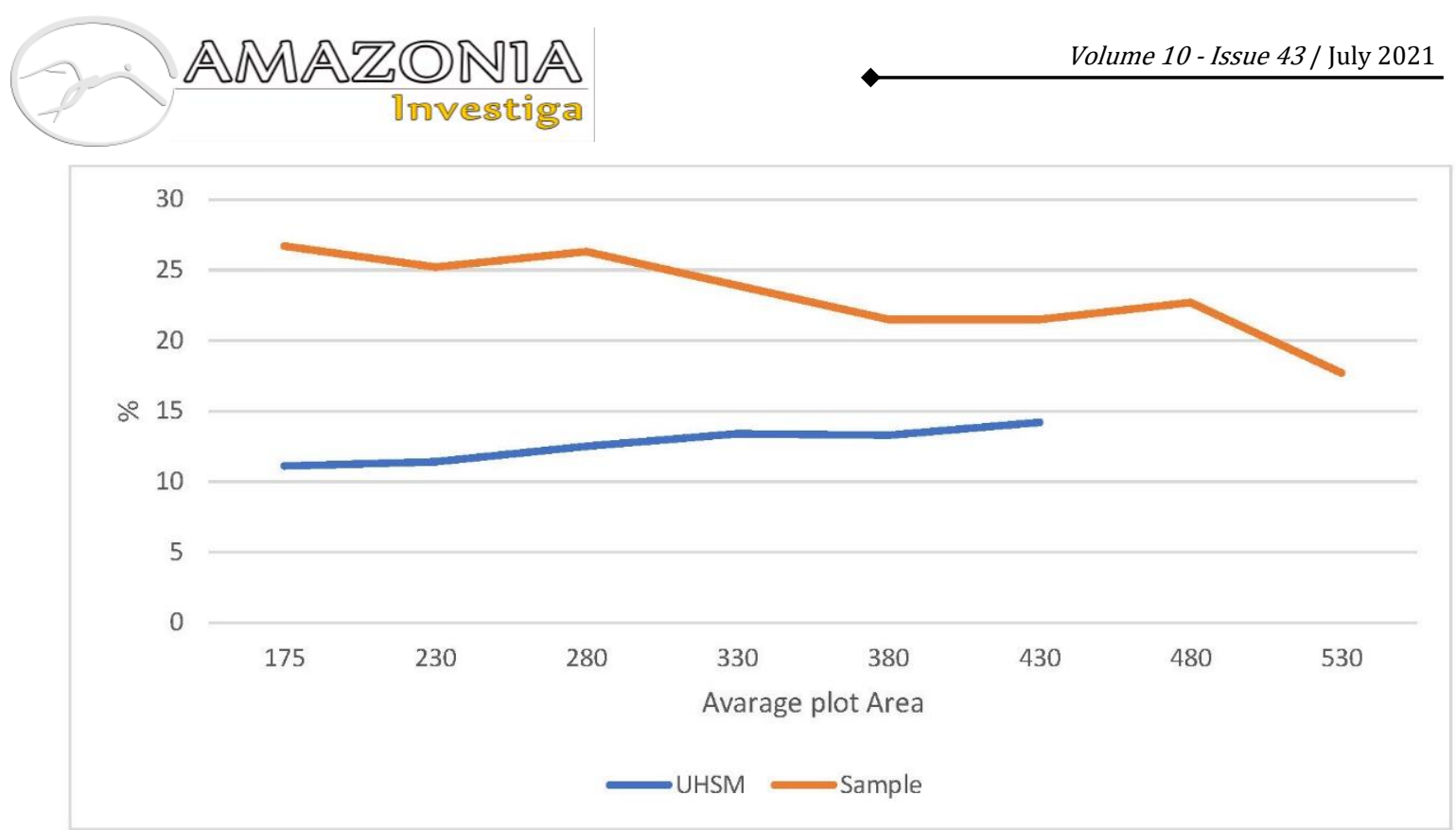

Figure 4. The relationship between the circulation floor area ratios and the average plot areas of the (UHSM) and case study sample (Researchers).

However, a comparison of the structure floor area ratio between the UHSM standards and the case study samples could not be concluded because there are no indicators in the standard for this area. In addition, the standard has adopted different construction materials and structural systems to guarantee the applicability of the standard to all of Iraq's provinces. It should be noted that the ratio of the structural floor area dropped from $16.1 \%$ to $10.9 \%$ within the case study samples.
For the open space floor area ratio for this case study [Figure 5], the increase from $36.8 \%$ to $90.5 \%$ comes unexpectedly with increasing house plot area. This means that the majority of the plot is occupied by gardens and open spaces, which implies the loss of urban land. In the UHSM standards, the decrease in the open area ratios from $11.1 \%$ to $10.5 \%$ is at an acceptable level.

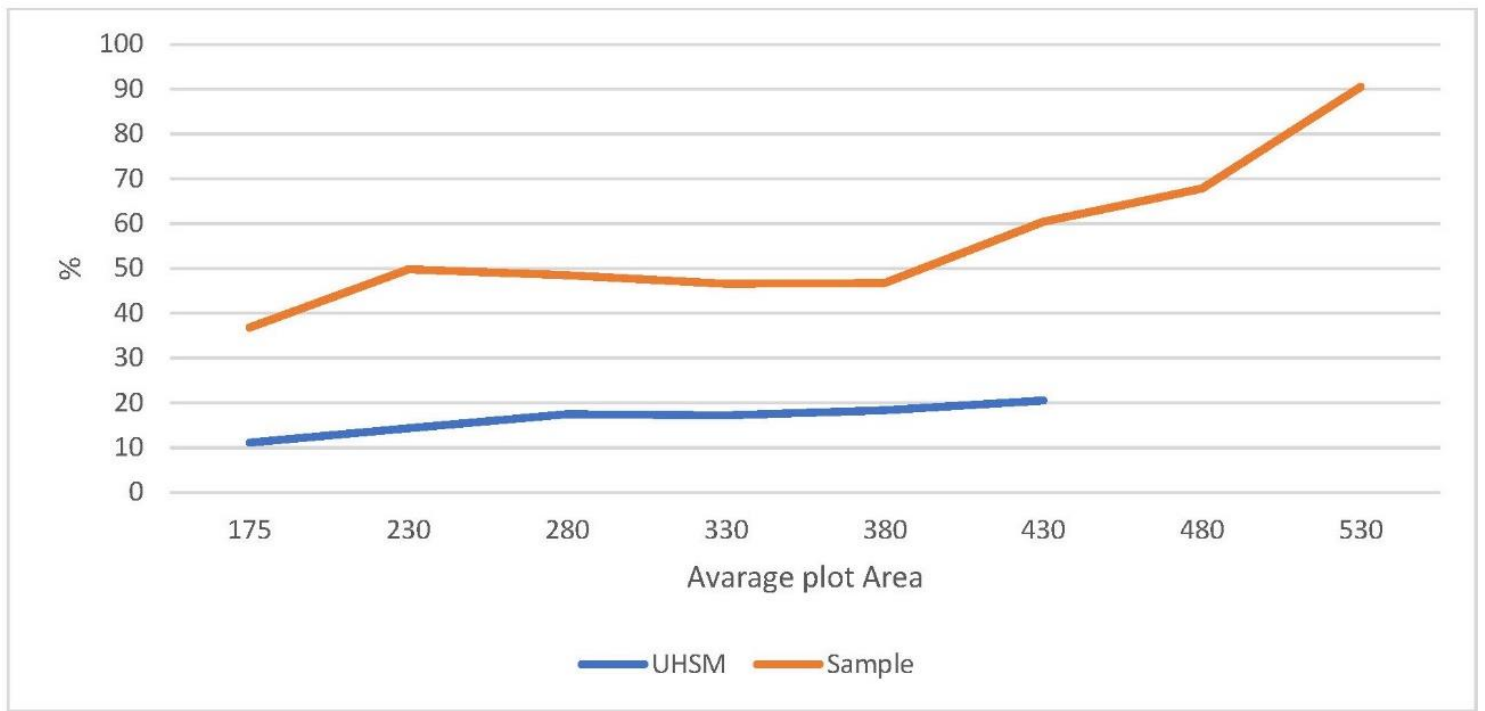

Figure 5. The relationship between the open floor area ratios and the average plot areas of the (UHSM) and case study sample (Researchers).

There is a significant difference in floor area ratios between those observed in the case studies and those proposed by the UHSM. The case study shows more heterogeneity than the UHSM standards as follows [Figure 6].
The habitable floor area ratio indicates a declining trend and ranges between 48.1 and $66.2 \%$. The service floor area ratios show a random distribution through the graph and a range between 20.1 and $30.9 \%$. In contrast to 
other component ratios, both the ratio of circulation floor area and the ratio of structure floor area show a decreasing trend of $26.7-17.7 \%$ and $16.9-10.9 \%$, respectively. The open floor area ratio rises sharply and ranges from 36.8 to $90.5 \%$.

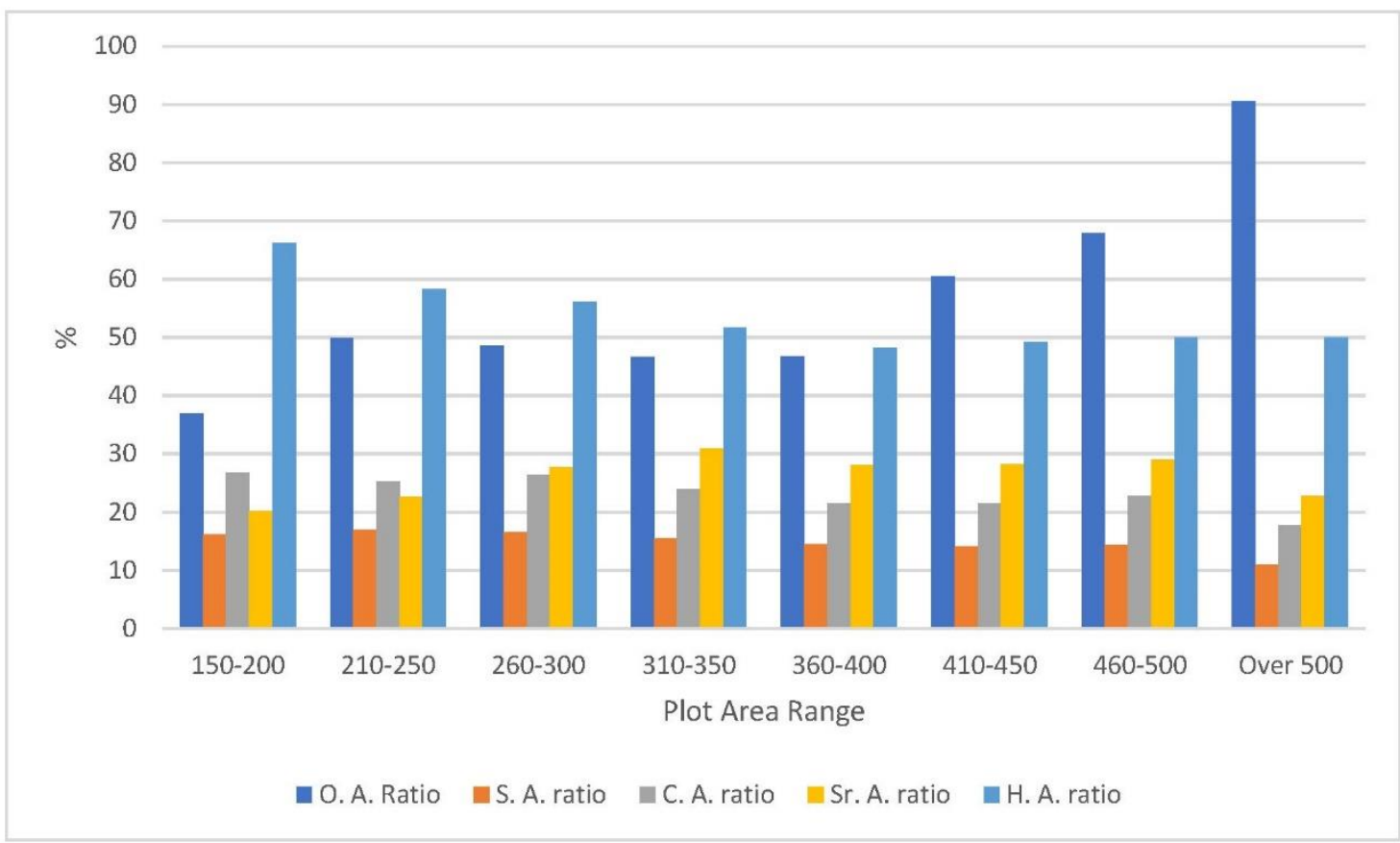

Figure 6. All components floor area ratio to the built-up area of the case study samples (Researchers).

\section{Conclusions}

A habitable environment can be achieved only if developments, environmental issues and problems are given equal emphasis in urban housing development. Basic human needs must be fulfilled with improved living standards to sustain our ecological systems effectively. Therefore, greater integration of land use planning with social, economic, and environmental considerations is needed. The efficiency of any building can be measured by the total habitable area compared to its building size, and the value of this ratio is not realized in the private housing sector.

Despite the importance of all mentioned components in determining any house's liveability, such as the service area (the spaces provided for preparing food, storage, and bathing), and the circulation area (the space provided for supporting accessibility in terms of a horizontal and vertical movement system), the habitable spaces in dwellings remain at the forefront of the occupant's most important vital space.

While investment firms in the residential sector offer many options of single-family house units compared to the limited options offered by (UHSM) standards, these firms are trying to maximize their profits at the expense of reducing the built-up area to the plot area occupied by the house; this is done without any consideration of the urban land loss and is concluded from the large increase in the values of the open spaces ratio. In the long term, this will lead to a large waste of available resources, negatively affecting social sustainability, especially in large, crowded cities.

There was a significant imbalance in the number of habitable floor area ratios to the other component area ratios within the case study samples that were monitored. This imbalance reduces the efficiency of the exploitation of the land on which a single house is situated, in particular the large plots (over 500 sq. m), which is the opposite of what is expected, and contrasts with the criteria set out by the UHSM, which showed homogeneity in general.

Although both the service floor area ratio and the circulation floor area ratio increase gradually with an increasing of average built-up area for the dwelling, these ratios are not consistent with the plot area. This result indicates a lack of conventionality and habitability of the house and negatively reflects house efficiency and occupant satisfaction. 


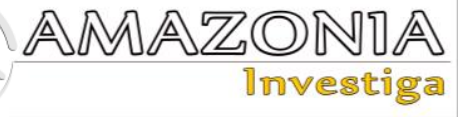

Attitudes towards stable ratios of floor area in manuals are specific to places and experiences: they come to reflect quite fundamental beliefs about the utility and purpose of houses. Where housing is seen as an investment commodity, standards are likely to be viewed as a threat to $n$ that investment, but none can deny the importance of houses to the life and future of the family. For those occupying residences, suitable housing standards mean health and safety.

The foregoing analysis indicates the need for the authorities and institutions responsible for the housing sector to reconsider the design criteria that determine the ratios of each floor area in a single-family house. In addition, they need to force the building companies operating in this field to comply with these standards to increase the efficiency of housing output and maximize the exploitation of urban land. Another goal is to make those houses capable of reconciling the economic criteria with the criterion of fulfilling the family's requirements in terms of maintaining the minimum level that enables the family to take advantage of the design spaces of the house and keep it from being replaced or modified. With regard to 'sustainable communities' in Iraq's real state, a well-regulated and sustainable real estate market needs to be established to reduce the abovementioned distortions. The regulatory framework of building standards and administrative procedures must be reviewed and changes must be made where needed.

\section{Bibliographic references}

Abrahem, S. A. (2018) Typology of Urban Housing and Politics in Baghdad: From Statesubsidized Housing to Privatized Gated Communities (Unpublished doctoral dissertation), Graduate School of the University of Cincinnati, OH. USA.

Al Khafajy, A. M., Hussain, A. M., \& Abood, A. A. (2018). Building performance. Iraqi Journal of Architecture and Planning, 10(1), 255-277. DOI: 10.36041/iqjap.v10i1.194.

Al-Hafith, O., Satish, B. K., Bradbury, S., \& Wilde, P. (2018). A systematic assessment of architectural approaches for solving the housing problem in Iraq. Frontiers of Architectural Research, 7(4), 561-572. DOI: 10.1016/j.foar.2018.07.001

Allen, J., Barlow, J., Leal, T., Maloutas, T. \& Padovani, L. (2008). Housing and Welfare in Southern Europe. Delhi: Blackwell Publishing Ltd., ISBN: 9781405103077

Al-Qemaqchi, N., \& Rauof, T. (2019) Open Space Criteria for Residential Complexes; Evaluation and implementation of urban housing standards. The Scientific Journal of Cihan University- Sulaimanyia, 3(1), 1-12, DOI: 10.25098/3.1.1

Al-Shaibani, A. A., \& Popov, A. D. (2019). Analysis of Iraq housing policies as a relationship between design and economy. IOP Conference Series: Materials Science and Engineering. DOI: 10.1088/1757899x/698/3/033002.

AL-Temimi, K., and Al-Saidi, M. (2014), The efficiency of residential units and future prospects in the city of Muqdadiyah. Diyala humanity Research Journal, (62), 161-195.

Chowdhury, I. (1985). Housing and Space Standards: Human Needs and Regional Factors. In R. Powell (Ed.), Regionalism in Architecture. Singapore: Concept Media Pte Ltd. ISBN: 9971845288

ECOM \& UN-Habitat (2010), Iraq National Housing Policy, Decentralized Strategies, and Institutional and Regulatory Reforms, April 21, 2010. Retrieved from: https://www.moch.gov.iq/uploads/enseasatalika nalwatanyah.pdf (accessed 12 Jan. 2020).

Femenias, P., \& Geromel, F. (2019). Adaptable housing? A quantitative study of contemporary apartment layouts that have been rearranged by end-users. Journal of Housing and the Built Environment, 35(2), 481-505. DOI: 10.1007/s10901-019-09693-9

Franklin, B. (2006). Housing transformations: shaping the space of twenty-first century living. London: Routledge. ISBN: 9780415336192

Gallent, N., Madeddu, M., \& Mace, A. (2010). Internal housing space standards in Italy and England. Progress in Planning, 74(1), 1-52. DOI: 10.1016/j.progress.2010.04.001.

Hooper, A., \& Nicol, C. (1999). The design and planning of residential development: standard house types in the speculative housebuilding industry. Environment and Planning B: Planning and Design, 26(6), 793-805. DOI: 10.1068/b260793.

Howden-Chapman, P., Roebbel, N., \& Chisholm, E. (2017). Setting Housing Standards to Improve Global Health. International Journal of Environmental Research and Public Health, 14(12), 1542., DOI: 10.3390/ijerph14121542

Kurdistan Regional Government-Iraq, Investment Board Department of Information and Studies, (2019). List of Licensed Projects in Kurdistan Region Approved by BOI \& Governorates DGs. From 2006/08/01 to 2019/07/28. Retrieved from http://www.kurdistaninvestment.org/docs/licens ed_projects.pdf (accessed 10 May 2020).

Mahmood, T. (2011). Evaluation of housing of low-income projects in Ramadi city Anbar. Anbar Journal for Engineering Science, 4(2). 
$125-140$.

https://www.iasj.net/iasj/download/aa454f5d4bd $11 \mathrm{~b} 73$

Matthew, C. (2009). Design quality in new housing: learning from the Netherlands. New York: Taylor \& Francis. ISBN: 9780415447706 Ministry of Housing and Construction (1983), Housing Technical Standards and Codes of PracticelReport two. Retrieved from: https://investpromo.gov.iq/wpcontent/uploads/2013/04/URBAN-HOUSINGSTANDARDS.pdf. (accessed 1 May 2020).

Park, J. (2017) One Hundred Years of Housing Space Standards. (n.d.). housingspacestandards. Retrieved from: http://housingspacestandards.co.uk/assets/spacestandards_onscreen.pdf. (accessed 1 January 2020).

Pedro, J. (2009). How small can a dwelling be? A revision of Portuguese building regulations. Structural Survey, 27(5), 390-410. DOI: 10.1108/02630800911002648.

Rapoport, A. (1991). House form and culture. Englewood Cliffs, NJ: Prentice-Hall.

Salih, H. M. (2015) Residential Housing Development in Kurdistan Region Government of Iraqi Federal (Unpublished master's thesis), Faculty of Civil Engineering, Universiti Teknologi-Malaysia. https://core.ac.uk/download/pdf/42920893.pdf. Tabak, V., Vries, B. D., \& Dijkstra, J. (2010). Simulation and Validation of Human Movement in Building Spaces. Environment and Planning B: Planning and Design, 37(4), 592-609. DOI: 10.1068/b35127.

Thabit, N. M., Yonis, G. M., \& Aldewachi, M. H. (2007). Factors Affecting the Occupation Deviation of Dwelling Units Spaces in New Districts in Mosul. AL-Rafdain Engineering Journal (AREJ), 15(4), 62-79. DOI: 10.33899/rengj.2007.45252.

The Iraqi Central Statistical Origination (ICSO), (2009) Annual Abstract of Statistics 2010-2011,
Section 10: Health and Vital statistics, Administrative units and their area as in 2009. Retrieved from: http://www.cosit.gov.iq/AAS/AAS2012/section _10/1.htm (accessed 10 January 2020).

The Iraqi Ministry of Planning (2018) Summary Report of National Development OPlan 2018 2022, Baghdad. Retrieved from: https://www.iraqjccme.jp/pdf/archives/nationald evelopmentplan2018_2022.pdf. (accessed 21 November 2019).

Towers, G. (2000). Shelter is not enough: transforming multi-storey housing. Bristol: Policy Press. ISBN: 1861341563

UN-Habitat \& World Bank/IFC. (2006) Iraq Housing Market Study-Main Report, December 2006, Baghdad. Retrieved from: https://www.humanitarianlibrary.org/sites/defau lt/files/2013/05/4997_65700_IHMS_Main_Rep ort.pdf. (accessed 21 November 2019).

Urban Housing Standards Manual (UHSM) (2010). Republic of Iraq, Ministry of Construction \& Housing State, Commission of Housing Studies Section. https://investpromo.gov.iq/wpcontent/uploads/2013/04/URBAN-HOUSINGSTANDARDS.pdf

World Bank Group, Middle East and North Africa Region (2018), Iraq Economic Monitor from War to Reconstruction and Economic Recovery, Spring 2018. Retrieved from: https://www.worldbank.org/en/country/iraq/pub lication/iraq-economic-monitor---fall-2019 (accessed 10 January 2020).

Yakob, H., Yusof, F. \& Hamdan, H. (2013) Sustainable Urban Housing Development through Planning Mechanism: Issues and Challenges, Asia Pacific Network for Housing Research Conference, Faculty of Built Environment, University of Malaya Vol: APNHR2013 Proceedings, E-ISBN 978983445034. 